\title{
Impact of the contamination time by Escherichia coli on biofilm formation in surgical instruments
}

\author{
Impacto do tempo de contaminação por Escherichia coli na formação de biofilme em instrumentos cirúrgicos \\ Impacto del tiempo de contaminación por Escherichia coli en la formación de biofilm en instrumentos quirúrgicos
}

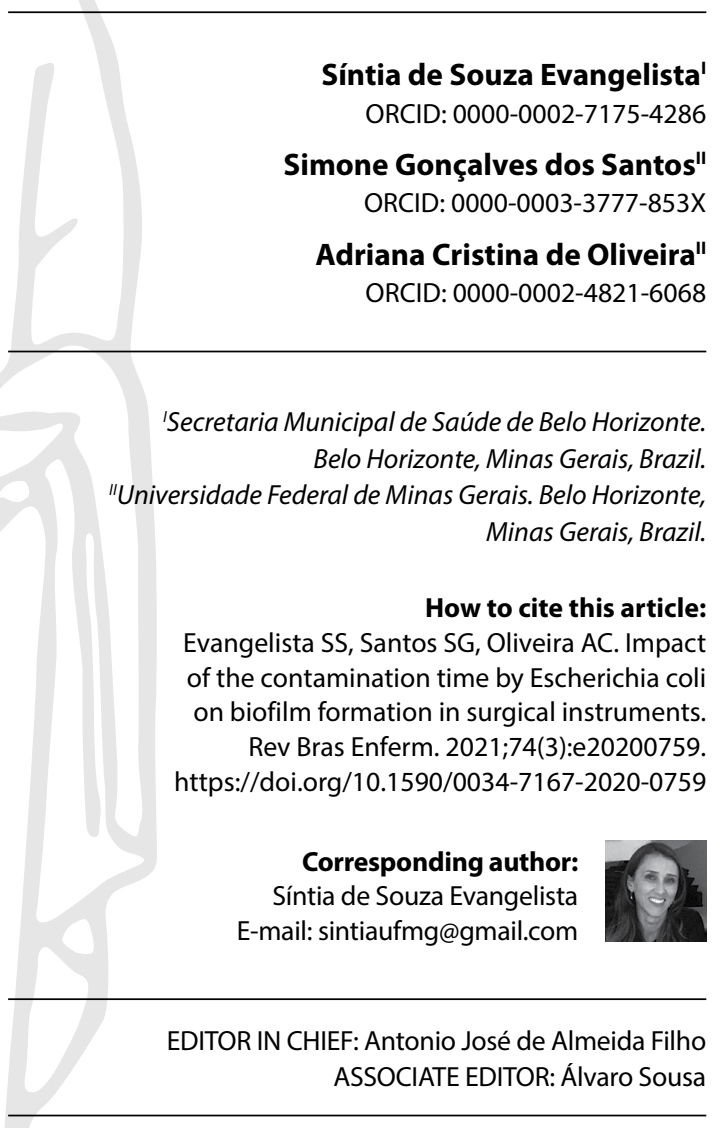

Submission: 07-07-2020

Approval: 11-16-2020

\begin{abstract}
Objectives: to evaluate the microbial load and adherence of Escherichia coli in different areas of the surgical instrument surface exposed to experimental contamination over time. Methods: experimental study in which fragments of crile forceps (serrated, rod and rack) were contaminated by immersion in Tryptic Soy Broth, containing $10^{6} \mathrm{CFU} / \mathrm{mL}$ of E. coli, for 1, 2, 4, 6, 8, 12 and 24 hours. Microbial load and bacterial adherence were evaluated using microbiological culture and scanning electron microscopy, respectively. Results: there was an increase in the microbial load on the surgical instrument, proportional to the contamination interval, ranging from $10^{2}$ after 1 hour to $10^{5} \mathrm{CFU} / \mathrm{cm}^{2}$ in 24 hours. The presence of exopolysaccharide was detected after two hours of contamination. Conclusions: microbial load and adhesion of E. coli increased over time, reaching $10^{5} \mathrm{CFU} / \mathrm{cm}^{2}$ after 24 hours of contamination, starting biofilm formation after two hours.

Descriptors: Biofilms; Escherichia coli; Surgical Instruments; Patient Safety; Equipment Contamination.
\end{abstract}

\section{RESUMO}

Objetivos: avaliar a carga microbiana e a aderência de Escherichia coli em diferentes áreas da superfície de instrumento cirúrgico exposto à contaminação experimental ao longo do tempo. Métodos: estudo experimental em que fragmentos de pinças crile (serrilha, haste e cremalheira) foram contaminados por imersão em Tryptic Soy Broth, contendo $10^{6} \mathrm{UFC} / \mathrm{mL}$ de E. coli, por 1, 2, $4,6,8,12$ e 24 horas. A carga microbiana e a aderência bacteriana foram avaliadas com uso de cultura microbiológica e microscopia eletrônica de varredura, respectivamente. Resultados: verificou-se aumento da carga microbiana no instrumento cirúrgico, proporcional ao intervalo de contaminação, variando de $10^{2}$ após 1 hora a $10^{5} \mathrm{UFC} / \mathrm{cm}^{2} \mathrm{em} 24$ horas. A presença de exapolissacarídeo foi detectada após 2 horas de contaminação. Conclusões: carga microbiana e aderência de $E$. coli aumentaram ao longo do tempo, atingindo $10^{5} \mathrm{UFC} / \mathrm{cm}^{2}$ após 24 horas de contaminação, iniciandose formação de biofilme após 2 horas.

Descritores: Biofilmes; Escherichia coli; Instrumentos Cirúrgicos; Segurança do Paciente; Contaminação de Equipamentos.

\section{RESUMEN}

Objetivos: evaluar la carga microbiana y adherencia de Escherichia coli en diferentes áreas de la superficie de instrumento quirúrgico expuesto a la contaminación experimental a lo largo del tiempo. Métodos: estudio experimental en que fragmentos de tenacillas quirúrgicas (sierra, asta y cremallera), contaminados por inmersión en Tryptic Soy Broth, conteniendo $10^{6} \mathrm{UFC} / \mathrm{mL}$ de E. coli, por 1, 2, 4, 6, 8, 12 y 24 horas. La carga microbiana y la adherencia bacteriana evaluadas con uso de cultivo y microscopia electrónica de barredura, respectivamente. Resultados: verificó aumento de la carga microbiana en el instrumento quirúrgico, proporcional al intervalo de contaminación, variando de $10^{2}$ tras 1 hora a $10^{5} \mathrm{UFC} / \mathrm{cm}^{2}$ en 24 horas. La presencia de polisacárido detectada tras 2 horas de contaminación. Conclusiones: carga microbiana y adherencia de $E$. coli aumentaron a lo largo del tiempo, atingiendo $10^{5} \mathrm{UFC} / \mathrm{cm}^{2}$ tras 24 horas de contaminación, iniciándose formación de biopelícula tras 2 horas.

Descriptores: Biopelícula; Escherichia coli; Instrumentos Quirúrgicos; Seguridad del Paciente; Contaminación de Equipamientos. 


\section{INTRODUCTION}

Every year, millions of surgeries are performed, and this number is growing ${ }^{(1)}$. In 2004, it was estimated that about 234.2 million surgical procedures were performed, corresponding to one surgery per 25 human beings, rising to 312 million in $2012^{(1-2)}$. In Brazil alone, the number of diagnostic, clinical, surgical and transplant procedures exceeded 12 million interventions in $2019^{(3)}$. The use of sterile instruments to perform such procedures is an essential condition for safe and risk-free assistance.

Surgical site infection is a multifactorial adverse event, highlighting the use of the sterile instrument, free of contamination, as one of the factors that can contribute to greater safety of the procedure depending on the microbial load and virulence, the type of procedure and the immune response of the patient ${ }^{(4-6)}$.

As these are medical devices that can be processed, the surgical instrument must undergo a series of sequential and interdependent actions that include cleaning, drying, evaluation of integrity and functionality, preparation and sterilization, in order to allow its safe reuse ${ }^{(7)}$. Among these actions, cleaning is pointed as a critical point, because, when properly performed, it promotes the removal of dirt, aiming at reducing the levels of microorganisms, endotoxins, proteins and blood, a fundamental condition to reach the sterility of the surgical instrument after processing ${ }^{(8-9)}$.

Among the factors that can interfere with the quality of the cleaning, pre-cleaning is noteworthy. This step consists in the application of humidification maintenance measures, reduction of exposure to contamination and early transport, directed to the surgical instrument from the point of use until the beginning of cleaning, in the central material and sterilization ${ }^{(8)}$. The recommendations point to the need to start cleaning early, still in the operating room, avoiding the drying up of blood and secretions, as well as the implantation of a flow that ensures fast transport to the processing unit ${ }^{(6-11)}$. The design features, such as the presence of critical areas, common in most surgical instruments such as joint, jaw and ratchet, more prone to dirt retention and therefore more difficult to be properly cleaned, are also highlighted ${ }^{(10)}$.

Whether it's because it doesn't adhere to good processing practices or its challenging design, the permanence of microorganisms and organic matter on the surface of the surgical instrument can facilitate its adherence and enable the formation of biofilms. These are defined as an aggregate of microbial cells adhered to a surface irreversibly, protected by an extracellular polymeric substance matrix (Extracellular Polymeric Substance-EPS), which acts contributing to cellular cohesion and to the increase of its resistance, which makes it difficult to eliminate them ${ }^{(12-13)}$. However, few studies address the early times of biofilm formation, especially in surgical instrument ${ }^{(14)}$.

Thus, due to the reality of many health institutions, in which the processing of the surgical instrument cannot occur immediately after use, it is questionable: What is the impact of the contamination time before cleaning in relation to bacterial adherence in different areas of the surface of the surgical instrument?

\section{OBJECTIVES}

To evaluate the microbial load and adherence of Escherichia coli in different areas of the surgical instrument surface exposed to experimental contamination over time.

\section{METHODS}

\section{Ethical aspects}

Because it is an experimental research, in which the object of study does not involve human beings, observing the Resolution $466 / 2012$ of the National Health Council, it became unnecessary the submission to the Ethics and Research Committee.

\section{Design, period and place of study}

It was an experimental study, conducted between July and December 2018, in the oral microbiology and anaerobic laboratory of the Institute of Biological Sciences and the Microscopy Center (MC), both at the Federal University of Minas Gerais (UFMG).

\section{Sample}

Straight crile-type surgical forceps (ABC surgical instruments, São Paulo, Brazil) were used without previous use, made of AISI 420 stainless steel, used for the purpose of gripping the end of sectioned vessels during the surgical procedure. Each surgical instrument was sectioned in 1 centimeter fragments, representative of the areas of jaw, shank and ratchet (Figure 1).

For each analyzed time, three fragments were used, one representative of each region chosen from the surgical instrument, totaling 21 for each trial. Considering that the microbiological analysis was performed in biological triplicate and for microscopy another assay was conducted, 84 fragments were needed to perform the study.

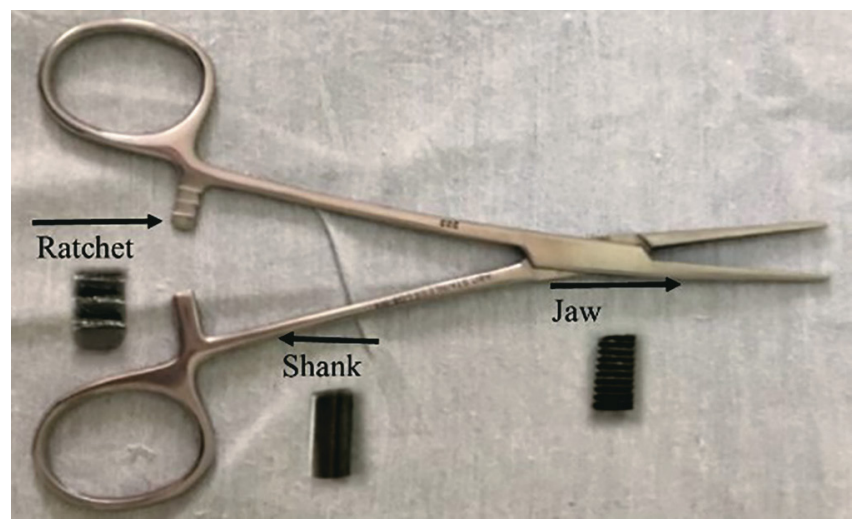

Figure 1 - Straight crile forceps $(14 \mathrm{~cm})$ and respective areas sectioned for analysis: ratchet, shank and jaw

The three areas were defined as they presented different challenges to the cleaning process: presence of serration, grooves in the ratchet and smooth surface on the shank.

\section{Study protocol}

The study was conducted according to the reference methodology published by Bjerka et al. and Pizzolito et $\mathrm{al}^{(15-16)}$. To ensure sterility, the fragments were submitted to automated cleaning in ultrasonic washer (USC-2800, Engesolutions`, São Paulo, Brazil) (40 $\mathrm{kHz}$ ), rinsed in distilled water, placed on absorbent paper for drying, packed in SMS (Spunbonded/Meltblow/Spunbonded) and sterilized by pressure-saturated steam (CS, Prismatec, Itu, São Paulo) at $121^{\circ} \mathrm{C}$, for 15 minutes. 
For contamination, a sample of E. coli (American Type Culture Collection [ATCC] 25922), kept refrigerated at minus $80^{\circ} \mathrm{C}$, was thawed in a Class II Biological Safety Cabinet (Veco ${ }^{\circ}$ Campinas, Brazil), sown in petri dish containing Tryptic Soy Agar (TSA) (Difco Laboratories Inc., Detroit, MI, USA) and incubated for 18-24 hours at $37^{\circ} \mathrm{C}$ in a bacteriological oven (Fanen ${ }^{\circ}$, Carandiru, Brazil).

Three to four isolated colonies were removed from this culture with the aid of a bacteriological loop in a Class II Biological Safety Cabinet and promptly inoculated in a test tube containing $3 \mathrm{~mL}$ Tryptic Soy Broth (TSB) (Difco Laboratories Inc., Detroit, MI, USA), submitted to homogenization in a tube agitator for approximately five seconds (Vortex-Genie 2, Daigger', fisher scientific, Bohemia United States). The optical density (OD) of the bacterial suspension was adjusted between 0.56 and 0.60 by means of spectrometry (Densi CHECK Plus, BioMerieux Inc ${ }^{\mathrm{TM}}$, Marcy-l'Étoile, France), at a wavelength of 580 nanometers (OD580), resulting in a concentration of approximately $1.5 \times 10^{8}$ colony forming units per milliliter (UFC/mL).

A micropipette (Gilson ${ }^{\mathrm{TM}}$, France) was used to aliquot and transfer a $50 \mu \mathrm{L}$ sample of the prepared bacterial suspension into vials containing $5 \mathrm{~mL}$ Tryptic Soy Broth (TSB) (Difco ${ }^{\circ}$ ) and resulting in a solution with $10^{6} \mathrm{UFC} / \mathrm{mL}$. To simulate the contamination, the three fragments of the sterile forceps (jaw, shank and ratchet) were transferred to these flasks with the aid of a sterile forceps.

This microorganism was chosen because it is one of the main pathogens causing intra-hospital infections and, among them, surgical site infections ${ }^{(17-18)}$, in addition to its recognized ability to form biofilms ${ }^{(12)}$. The bottles were threaded and incubated at $37^{\circ} \mathrm{C}$, under constant stirring of $100 \mathrm{rpm}$ on orbital shaker I10O+ACOP.E (Ovan', Barcelona, Spain), for 1, 2, 4, 6, 8, 12 and 24 hours.

After the respective incubation times, each bottle was removed from the equipment. In Biological Safety Cabinet (Veco ${ }^{\circ}$, Campinas, Brazil), the fragments contained in them were removed with the aid of a sterile forceps, deposited in a sterile flask and then rinsed six times with $3 \mathrm{~mL}$ of distilled water, using an automatic pipette (K1 AID, Kasvi',Brazil) for the removal of planktonic cells. The flasks were manually homogenized by five circular movements; and the solution, discarded. Each fragment was transferred separately to a sterile polypropylene tube (Eppi ${ }^{\mathrm{TM}}$; Eppendorf, Hamburg, Germany). The analysis of the fragments was performed by means of microbiological culture and scanning electron microscopy (SEM).

For microbiological analysis, in a Biological Safety Cabinet and with the aid of a micropipette, $1.1 \mathrm{~mL}$ of miliQ water was added to the tube containing the fragment. Then, these bottles were sealed and submitted to sonication, for five cycles of one minute, with an interval of one minute between them, in cell disruptor (frequency of $40 \mathrm{kHz}$ ) (Unique , Indaiatuba, Brazil) and, finally, exposed to homogenization in vortex type agitator for one minute. After serial dilution to $10^{-4}$ concentration in Biological Safety Cabinet, an aliquot of 50 $\mu \mathrm{L}$ was seeded in petri dish, in duplicate, on Tryptic Soy Agar (TSA) (Difco ${ }^{\circ}$ ), for cultivation and quantification of CFU/mL. The plates were incubated in a bacteriological oven (Fanen ', Carandiru, Brazil) at $37^{\circ} \mathrm{C}$, in an ambient atmosphere for 24 hours; and the number of colonies was manually quantified and converted to CFU/cm 2 of the analyzed fragment. The tests were conducted in biological triplicate.

The SEM fragments were deposited in a sterile polypropylene tube in Biological Safety Cabinet and immersed in $2 \mathrm{~mL}$ of $2.5 \%$ glutaraldehyde solution at $0.2 \mathrm{M}$ for 24 hours at $4{ }^{\circ} \mathrm{C}$. Later, with the help of a micropipette, the glutaraldehyde solution was discarded and replaced by distilled water, $2 \mathrm{~mL}$, twice, in order to promote the rinsing of these fragments. These were then transferred to a tube containing $1.5 \mathrm{~mL}$ of $0.2 \mathrm{M}$ phosphate buffer, sufficient to cover the entire sample, and stored at a temperature between $2{ }^{\circ} \mathrm{C}$ and $8{ }^{\circ} \mathrm{C}$ until transported to CM-UFMG.

In the microscopy center, the samples were submitted to secondary fixation, dehydration, drying up to the critical point of $\mathrm{CO}_{2}$, assembly in stubs and metallization, according to the service protocol. The samples were taken to the microscope, and at least five regions along the fragment were selected to check bacterial adherence.

\section{Analysis of the results}

The CFU count recovered from the fragments, in culture medium, was performed. The average of the values representing an aliquot of $50 \mu \mathrm{L}$, resulting from the duplicate, was calculated and converted, to obtain the number of CFU present in the total recovery solution $(1,100 \mu \mathrm{L})$. The value for each fragment evaluated in CFU/ $\mathrm{cm}^{2}$ was then obtained, after standardization, according to the respective areas: shank $\left(8.4 \mathrm{~cm}^{2}\right)$, jaw $\left(8 \mathrm{~cm}^{2}\right)$ and ratchet $\left(7.4 \mathrm{~cm}^{2}\right)$. Subsequently, the means of the triplicates were obtained; the data were converted to $\log _{10}$ and analyzed using Excel ${ }^{\circ}$ version 16.0.

\section{RESULTS}

The recovery of bacterial load from surgical instrument fragments (jaw, shank and ratchet) submitted to bacterial contamination by reference sample $E$. coli ATCC 25922, in the intervals of 1 , $2,4,6,8,12$ and 24 hours, are presented in Figure 2.

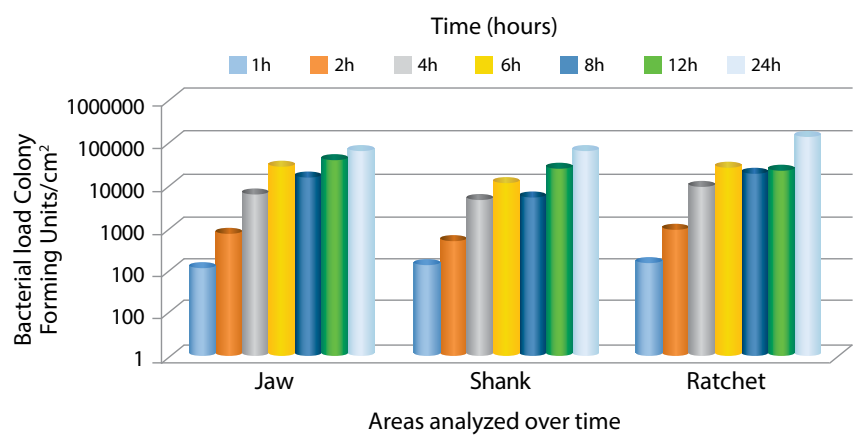

Note: $\mathrm{cm}$ - centimeters; $h$ - hours.

Figure 2 - Bacterial load in colony forming units (CFU) $/ \mathrm{cm}^{2}$, recovered from surgical instrument fragments, after different intervals of experimental contamination by Escherichia coli, Belo Horizonte, Minas Gerais, Brazil, 2018

The data demonstrate the elevation of the bacterial load over the analyzed times. After the first hour of contamination, it was possible to observe the recovery of $E$. coli in all analyzed fragments, being obtained a count around $10^{2} \mathrm{CFU} / \mathrm{cm}^{2}$. This same load was maintained until the time of two hours.

In the time of four hours, an increase in bacterial load was detected on a logarithmic scale, with the fragments showing an average of $10^{3} \mathrm{CFU} / \mathrm{cm}^{2}$. The same happened in the following interval, when the bacterial loads reached $10^{4} \mathrm{CFU} / \mathrm{cm}^{2}$, with six hours, being this average maintained until the time of eight hours, except for the shank fragment, in which there was a reduction to the average value of $10^{3} \mathrm{CFU} / \mathrm{cm}^{2}$. 
After 12 hours, there was an increase in the bacterial load in the fragments evaluated, and this variation was more pronounced in the shank fragment, whose load reached $10^{4} \mathrm{CFU} / \mathrm{cm}^{2}$. In the interval of 24 hours a bacterial load of $10^{4} \mathrm{CFU} / \mathrm{cm}^{2}$ was maintained for the shank and jaw areas, while in the ratchet an average of $10^{5} \mathrm{CFU} / \mathrm{cm}$ was recovered ${ }^{2}$.

When comparing the three different areas analyzed, it was noted that the bacterial load was similar in the three fragments analyzed over time, however the shank had the lowest microbial load between two and eight hours, while the ratchet was the region with the highest microbial load over time, except in the 12 hour time. Furthermore, it should be noted that the average values recovered in the jaw were close to those observed in the ratchet.

By means of SEM, the fragments were analyzed for their structure in order to determine bacterial adherence and biofilm formation over time (Fig. 3). The selected images refer to the areas of the fragments where the highest bacterial adhesion and/or structure suggestive of EPS formation was identified.

After 1 hour, in the jaw (Fig. 3A), shank (Fig. 3B) and ratchet (Fig. $3 C$ ) areas, the adhesion of scattered rods on the surface of the instrument, typical morphology of E.coli was observed.

In the time of two hours, it was observed, in jaw region (Fig. 3D), rods, grouped in an area of slit identified on the surface of the surgical instrument, with the presence of pili and production of amorphous, whitish material, suggestive of EPS. In this
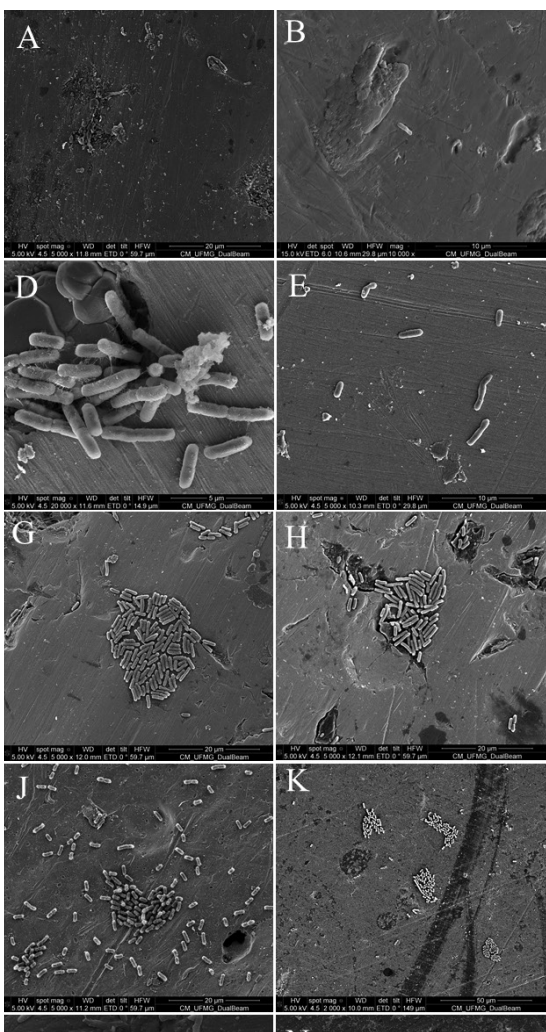

M

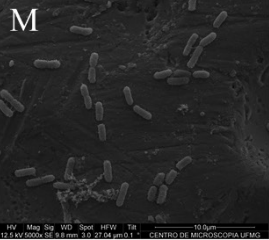

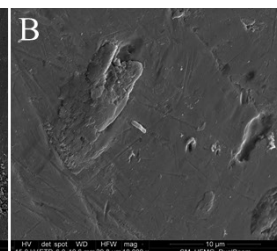
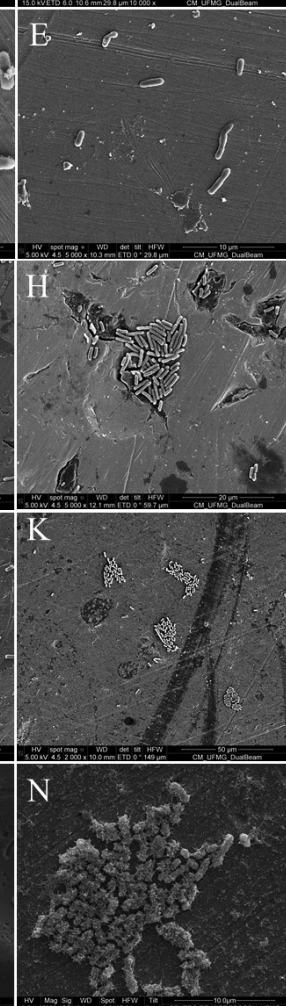
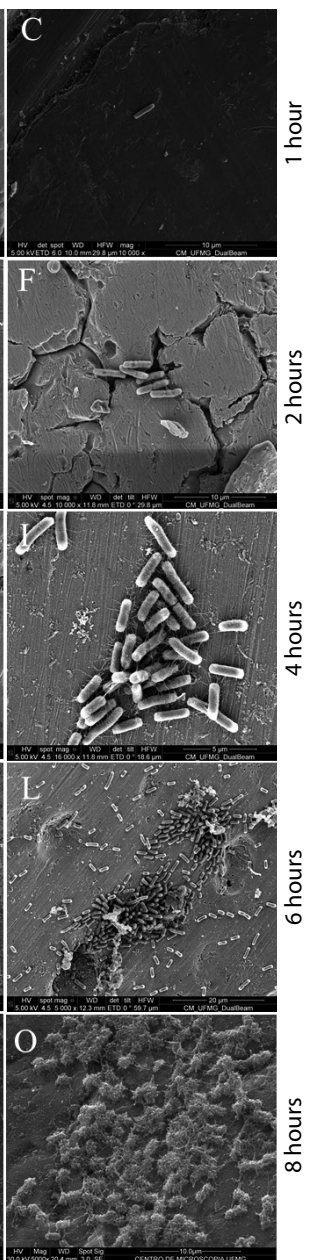

period, in the shank area (Fig. 3E), rods were identified as isolated, while in the ratchet (Fig. 3F), rods in the process of cell division, agglomerated in crevice region.

An increase in the concentration of microorganisms was observed after four hours in relation to the previous time in the jaw (Fig. 3G), shank (Fig. 3H) and ratchet (Fig. 3l) fragments. In the shank area, it is possible to observe its presence in grooves of the structure of the surgical instrument; and, in the ratchet, the expression of pili on the surface of the bacterial cell is evidenced.

In the jaw (Fig. $3 \mathrm{~J}$ ), after six hours, a grouping of agglomerated microorganisms was identified in the central area of the image and the presence of isolated cells in the adjacencies. In the shank fragment (Fig. 3K), a grouping of microorganisms was observed on the surface of the surgical instrument. In the ratchet (Fig. $3 \mathrm{~L}$ ), the presence of concentrated rods in the groove area was verified.

At the end of 8-hours (Fig. 3M), microorganisms dispersed on the surface and EPS production were observed. Similarly, the areas of shank (Fig. 3N) and ratchet (Fig. 30) presented a group of rods covered with amorphous material suggestive of EPS.

In relation to the previous times, it is highlighted that after 12 hours of contact with the microorganism, jaw (Fig. 3P), shank (Fig. 3Q) and ratchet (Fig. 3R) presented a high concentration of E. coli, which evolved in 24 hours to a surface full of microorganisms as seen in jaw (Fig. 3S), shank (Fig. 3T) and ratchet (Fig. 3U).
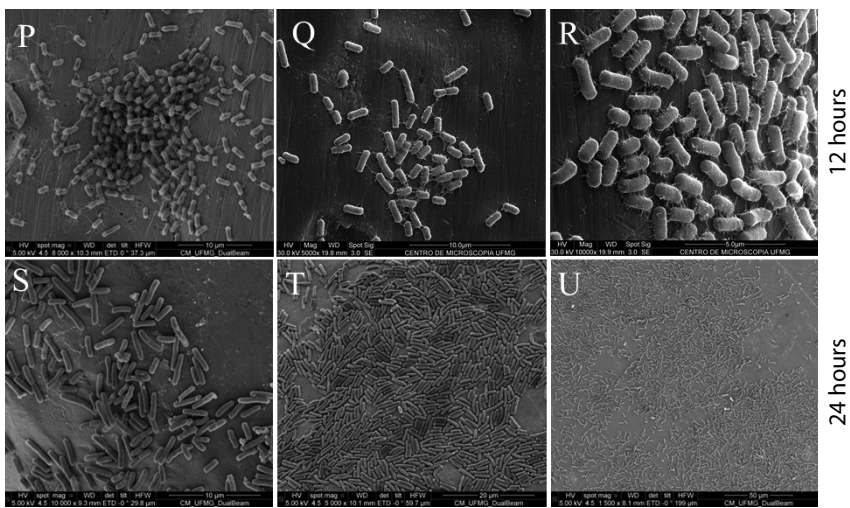

Note: $H V$ - acceleration voltage; spot - beam diameter; mag - magnification; WD - working distance; det - detector type; HFW - image width; MC - microscopy center; (A) Jaw (5,000X), (B) Shank (10,000X) and (C) Ratchet (10,000X) after 1 hour, with presence of isolated rods on the surface; (D) Jaw $(20,000 \times)$ after two hours, with typical E. coli rods grouped in area of slit of the surface of the surgical instrument, with presence of pili and production of amorphous material suggestive of EPS; (E) shank (5,000) after 2 hours, with isolated rods on the surface of the surgical instrument; $(F)$ ratchet $(10,000 \times)$ after 2 hours, with rods in the process of cell division agglomerated in slit; $(G)$ jaw $(5,000 \times)$ after 4 hours - it is observed increase in the concentration of bacteria in relation to the previous time; $(H)$ shank $(5,000 \times)$ after 4 hours, with clustering of rods in the groove area of the surgical instrument; (I) ratchet $(15,000 \times)$ after 4 hours, with clustering of rods with evidence of the expression of ribs on the surface of the microbial cell; (J) jaw (5,000X) after 6 hours, with clustering of microorganisms in the central area of the image and presence of isolated cells in the adjacencies; (K) shank $(2,000 \times)$ after 6 hours - islands with clustering of microorganisms on the surface of the surgical instrument; $(L)$ ratchet $(5,000 \times)$ after 6 hours, with presence of clustering of rods in the groove area of the surgical instrument; $(M)$ jaw $(5,000 \times)$ after 8 hours, showing microorganisms dispersed on the surface with EPS production; $(N)$ shank $(5,000 \times)$ and $(O)$ ratchet $(5,000 \times)$ after 8 hours, with grouping of microorganisms covered with amorphous material suggestive of EPS; $(P)$ jaw $(8,000 \times),(Q)$ shank $(5,000 \times)$ and $(R)$ ratchet $(10,000 \times)$ after 12 hours - there is a high concentration of E. coli in relation to previous times; (S) jaw $(10,000 \times),(T)$ shank $(5,000 \times)$ and $(U)$ ratchet $(1,500 \times)$ after 24 hours - enlargement of the area filled with microorganisms that agglomerate covering a large part of the surface of the surgical instrument.

Figure 3 - Scanning electron microscopy of surgical instrument fragments (jaw, shank and ratchet) after 1, 2, 4, 6, 8, 12 and 24 hours of Escherichia coli contamination ATCC 25922, Belo Horizonte, Minas Gerais, Brazil, 2018 
Although it is a new surgical instrument, during the images, it called attention to the presence of structural alterations like cracks, easily observed in the fragments of jaw (1,2 and 6 hours), ratchet ( 2 and 6 hours) and shank (4 hours).

\section{DISCUSSION}

The quality of the cleaning of the surgical instrument is of fundamental importance so that it can be reused safely. The early start of this procedure is widely advocated in the main processing guidelines ${ }^{(6-10)}$, However, it often does not represent the reality of several hospital institutions, where these instruments are kept, for prolonged periods, in contact with contaminants from the surgical act, such as the surgical site, the microbiota of the patient's skin or the team during the manipulation. In this sense, it was experimentally demonstrated that a contact period of 1 hour was sufficient to promote an average bacterial load of up to $10^{2} \mathrm{CFU} / \mathrm{cm}^{2}$ on the surface of a surgical instrument kept in contact with $E$. coli.

The increase in contact time led to an increase in the microbial load, reaching $10^{3} \mathrm{CFU} / \mathrm{cm}^{2}$ after 4 hours, $10^{4} \mathrm{CFU} / \mathrm{cm}^{2}$ in 6 hours and $10^{5} \mathrm{CFU} / \mathrm{cm}^{2}$ after 24 hours. Similar results were described in a surgical instrument also experimentally contaminated with $E$. coli, in which the microbial load, in the first 12 hours of incubation, varied between $10^{2} \mathrm{CFU} / \mathrm{cm}^{2}$ and $10^{4} \mathrm{CFU} / \mathrm{cm}^{2}$, reaching $10^{6} \mathrm{CFU} /$ $\mathrm{cm}^{2}$ in 24 hours ${ }^{(19-21)}$.

As noted, the delay in the beginning of processing allowed the achievement of levels of microbial load above those expected $\left(10^{5} \mathrm{CFU} / \mathrm{cm}^{2}\right)$ for the surgical instrument after 24 hours. Studies that evaluated the recovery of microorganisms on the surface of the surgical instrument after use verified levels of contamination around $10^{2}$, up to $10^{4} \mathrm{CFU} /$ instrument, depending on the site addressed $^{(21-23)}$. In these publications, however, the microbial load was analyzed under ideal processing conditions, i.e., right after the surgical procedure and may have been underestimated in terms of the real time in which they are normally processed.

When the three different areas were compared, for the same time analyzed, it was found that fragments of jaw and ratchet generally had a higher microbial load than that recovered in shank. This finding can be justified by the irregularities present on the surface of the fragments of jaw and ratchet both macroscopically and microscopically. The design of the surgical instrument can act by making it difficult to remove dirt during the cleaning stage ${ }^{(24)}$. In health products containing joints, serrations, lumen or with irregular surface processed several times during their useful life, analyzed after sterilization, the presence of proteins was verified in levels up to 100 times higher than recommended, besides the presence of biofilms ${ }^{(25)}$. Therefore, in addition to accumulating a greater bacterial load, these areas present an even greater challenge to their removal during processing.

In a complementary way to the analysis of the bacterial load, the images produced by SEM allowed the identification of the evolution over time of the microbial adherence to the surgical instrument. After 1 hour of contact with the contaminant, the presence of bacteria adhered to the surface could be verified. The adhesion process initially occurs through weak interactions with the surface resulting from a balance between the attractive and repulsive forces. In the case of $E$. coli, the expression of scourge helps in the active motility of this microorganism, facilitating its approach $^{(14)}$. This process is influenced by characteristics of the microorganism (species, concentration, presence of cellular appendages and electrical charge), the surface (chemical composition, roughness and electrical charge) and the surrounding environment (temperature, availability of nutrients such as blood, proteins and body secretions, $\mathrm{pH}$ and flow conditions) ${ }^{(11)}$.

At this early stage of microbial adhesion, there may be an increase of up to ten times in the resistance to its removal compared to the planktonic form of the cell ${ }^{(26)}$, However, in general, they can still be easily removed by cleaning. The contact of the surgical instrument with either the surgical site or the microbiota of the patient's skin or the team during manipulation are factors that can favor microbial adherence, thus emphasizing the importance of removing dirt early, even during the surgical procedure, by removing the coarse, visible dirt ${ }^{(7-9)}$.

Subsequently, mechanisms such as the formation of pili or fimbriae and the expression of adhesion proteins promote a strong adhesion by specific molecular interactions known as "irreversible"(13-14). This phase was observed in a time of 2 hours, in the jaw fragment, when the presence of small capillary structures emerging from the bacterial surface was noted, helping to anchor the cells to the surface of the surgical instrument. After initial fixation of the microbial cell to the surface, the adhesion can become strong in about seconds or minutes ${ }^{(27)}$.

Once immobilized to the substrate, multiplication begins on the contact surface with the formation of a monolayer of microorganisms, grouped as micro-colonies in a continuous process of biofilm maturation ${ }^{(14)}$. During this period, cellular cohesion and cell-cell adhesion are maintained mainly by the production of EPS, pili action and synthesis of adhesives ${ }^{(27)}$. In this study, EPS formation can be identified after 2 hours of contact with contaminant.

It is thus perceived that a long waiting time before processing can lead to the ineffectiveness of routinely used protocols, as they increase the challenges of the cleaning process, both in terms of removing a high microbial load and in terms of the cohesive force of the cells arranged on the surface of the material. Then, it is noted that, besides the recommendation of early start of the cleaning of the surgical instrument, its immediate transport is fundamental ${ }^{(7-9)}$, in up to 2 hours, to start the processing in the central material and sterilization in order to achieve effective cleaning and, in turn, the safety of the surgical patient. In a study that evaluated orthopedic surgical instruments experimentally contaminated by bone fragments and microorganisms, it was observed that a prolonged period of contamination before processing ( 180 minutes) resulted in the recovery of bacteria, even after steam sterilization saturated under pressure ${ }^{(28)}$.

Furthermore, it should be noted that only the reduction of the levels of microorganisms is not sufficient to ensure the cleanliness of the surgical instrument, being used the evaluation of other components such as the presence of protein ${ }^{(22)}$. When not removed during cleaning, residual organic matter can act as a physical barrier, protecting microorganisms trapped inside from contact with the sterilizing agent, and can also compose a conditioning film formed by the adsorption of molecules such as proteins, lipids and polysaccharides resulting from the precipitation of body fluids on the surface of the surgical instrument, facilitating 
microbial adherence ${ }^{(11,27)}$. In practice, the presence of blood during the surgical procedure can favor bacterial multiplication since it can be used as a source of nutrition ${ }^{(11)}$.

Thus, considering that no type of organic matter, such as sheep's blood, generally used in similar experiments, was included in this experiment, it can be inferred that, although EPS formation took place within 2 hours, this period could have been shorter. The addition of $5 \%$ blood during experimental contamination of surgical instruments can increase the concentration of protein adsorbed to the surface of the surgical instrument by up to 10 times $^{(29)}$. Thus, if we think about the practice, when, during the contamination, we will have the presence of microorganisms, blood, besides other dirt, the adherence can occur even faster than the observed one.

Practices such as the use of alcohol on the surface of the surgical instrument during pre-cleaning, although related to the reduction in microbial load, can increase protein adsorption, especially in the presence of blood, reducing the ability to remove them in cleaning by up to $60 \%{ }^{(29-30)}$. Thus, despite its recognized bactericidal action, it is likely that the use of alcohol acts on organic matter by promoting dehydration and increasing its mechanical resistance, which may facilitate its fixation and the formation of biofilm. This situation is particularly problematic in instruments contaminated by prion protein, related to the transmission of Creutzfelt-Jacob disease, which is not inactivated during sterilization.

The maintenance of humidification, at this stage, has shown a relevant role to the quality of the processing of products for health, by helping to prevent the adherence of dirt to the surgical instrument ${ }^{(31-32)}$, especially in those cases where they are not transported immediately after use. Thirty minutes of dryness are enough to make it difficult to remove the dirt adhered to the surface of the surgical instrument ${ }^{(31)}$. However, even under humidification, transport to the material and sterilization plant should be prioritized, since contaminated instruments kept immersed in water, even for a long time, present an increase in microbial load ${ }^{(20-21,29)}$.

The challenge of cleaning the surgical instrument can still be affected by the presence of alterations in its microstructure, observed in this study during the performance of SEM. The presence of these fissures can contribute to shelter microorganisms, acting as potential sites for bacterial adherence or dirt retention during clinical use and reflecting on the quality of surgical instrument cleaning, especially when submitted to manual cleaning, since the bristles of the brushes will hardly reach these sites $^{(24)}$.

Thus, the concern with cleaning is justified because it is the main phase of the processing of health products, evidenced by the risk of fixation of microorganisms according to the interval for their effective removal. Rigid protocols that aim to minimize this period between the use of the surgical instrument and its processing can have a positive impact on the reduction of several factors that hinder its processing. Early start of cleaning during use on the operating table, with the removal of coarse dirt from the surgical instrument by sterile moistened compresses, and immediate transport to the material center and sterilization after use $^{(6-11)}$ can strongly contribute to mitigate the risk related to the drying of organic matter on its surface - when this drying occurs, its removal is difficult and can contribute to the proliferation of microorganisms as well as to the occurrence of biofilm.

\section{Study limitations}

A limitation of this study was the use of only one microorganism in the experiment, and an analysis of the potential formation of poly-microbial biofilm, that is, formed by more than one type of microorganism, was not possible. It is also important to note that the microscopy technique does not allow scanning the entire surface of the surgical instrument, due to its extension, being standardized the evaluation of at least five areas along the fragment.

\section{Contributions to the Nursing Area}

This study contributes in a relevant way with strong scientific evidence to emphasize the importance and relevance of nursing performance in the practice of processing products for health. The early interval of bacterial adherence and biofilm formation in the surgical instrument is recorded, allowing the visualization of this microscopic process and its development; furthermore, it is clarified how it is possible and how important it is to interrupt its formation still in initial stages, emphasizing the fact that the processing begins already during the surgical act.

\section{CONCLUSIONS}

The quality of the processing of reusable health products has direct repercussions on the assistance provided and the assurance of patient safety. Cleaning, within the set of steps necessary for the safe reuse of surgical instruments, is an extremely complex process and involves several factors, such as its design, routines of services and human.

Microbiological analysis has shown that surgical instruments that remain in contact with contaminants present, over time, increased levels of microbial load and greater bacterial adhesion to their surface, which can impact the effectiveness of their cleaning and increase the challenge to the effectiveness of the sterilization process, especially when associated with the formation of biofilm. As noted, microbial adherence to the surgical instrument occurs rapidly, which demonstrates the importance of pre-cleaning followed by immediate transport for processing, thus emphasizing the need both for investment in good practices of care with the material, even during its use on the operating table, and the adherence of professionals to these recommendations. An additional challenge to the cleaning step may be the presence of structural damage to the surgical instrument, which may serve as a reservoir and then make it difficult to process these products safely.

\section{FUNDING}

This study was supported by the Fundação de Amparo à Pesquisa do Estado de Minas Gerais (FAPEMIG) by universal edict 2015, process APQ 02025-15.

\section{ACKNOWLEDGMENT}

The authors would like to acknowledge the center of Microscopy at the Universidade Federal de Minas Gerais (http://www.microscopia.ufmg.br) for providing equipment and technical support in experiments involving electron microscopy. 


\section{REFERENCES}

1. Weiser TG, Haynes AB, Molina G, Lipsitz SR, Esquivel MM, Uribe-Leitz T, et al. Estimate of the global volume of surgery in 2012: an assessment supporting improved health outcomes. Lancet 2015;385(Suppl 2):S11. https://doi.org/10.1016/S0140-6736(15)60806-6

2. Weiser TG, Regenbogen SE, Thompson KD, Haynes AB, Lipsitz SR, Berry WR, et al. An estimation of the global volume of surgery: a modelling strategy based on available data. Lancet 2008;372(9633):139-44. https://doi.org/10.1016/S0140-6736(08)60878-8

3. Ministério da Saúde (BR). Procedimentos hospitalares do SUS: por local de internação. Brasília, DF: Ministério da Saúde; 2019

4. Berríos-Torres SI, Umscheid CA, Bratzler DW, Leas B, Stone EC, Kelz RR, et al. Centers for disease control and prevention guideline for the prevention of surgical site infection. JAMA Surg. 2017;152(8):784-91. https://doi.org/10.1001/jamasurg.2017.0904

5. World Health Organization (WHO). Decontamination and reprocessing of medical devices for health-care facilities [Internet]. Switzerland:WHO; 2016[cited 2019 Oct 2]. Available from: http://apps.who.int/iris/bitstream/10665/250232/1/9789241549851-eng.pdf?ua=1

6. Dancer SJ, Stewart M, Coulombe C, Gregori A, Virdi M. Surgical site infections linked to contaminated surgical instruments. J Hosp Infect. 2012;81(4):231-8. https://doi.org/ 10.1016/j.jhin.2012.04.023

7. Ministério da Saúde (BR). Agência Nacional de Vigilância Sanitária (ANVISA). Resolução da Diretoria Colegiada n 15, de 15 de março de 2012. Dispõe sobre os requisitos de boas práticas para o processamento de produtos para a saúde e dá outras providencias [Internet]. Diário Oficial da União Brasília. 2012 [cited 2019 Oct 2]. Available from: http://bvsms.saude.gov.br/bvs/saudelegis/ anvisa/2012/rdc0015_15_03_2012.html

8. Caston-Gaa A, Ruparelia CS. Module 6. Processing surgical instruments and medical device. In: Curless MS, Ruparelia CS, Thompson E, Trexler PA, (Eds.). Infection prevention and control: reference manual for health care facilities with limited resources. Baltimore (MD): Jhpiego; 2018

9. Association of perioperative registered nurses (AORN). Guidelines for perioperative practice. Denver, CO: AORN; 2017

10. Instrument Reprocessing Working Group. Reprocessing of instruments to retain value. 11. ed. Gütersloh: Instrument Reprocessing Working Group; 2017

11. Roberts CG. The role of biofilms in reprocessing medical devices. Am J Infect Control. 2013;41(Suppl 5):S77-80. https://doi.org/10.1016/j. ajic.2012.12.008

12. Flemming HC, Wingender J, Szewzyk U, Steinberg P, Rice SA, Sataffan K. Biofilms: an emergent form of bacterial life. Nat Rev Microbiol. 2016;14(9):563-75. https://doi.org/10.1038/nrmicro.2016.94

13. Ripa R, Shen AQ, Funari R. Detecting Escherichia coli biofilm development stages on gold and titanium by quartz crystal microbalance. ACS Omega 2020;5(5):2295-302. https://doi.org/10.1021/acsomega.9b03540

14. Sharma G, Sharma S, Sharma P, Chandola D, Dang S, Gupta S, et al. Escherichia coli biofilm: development and therapeutic strategies. J Appl Microbiol. 2016;121(2):309-19. https://doi.org/10.1111/jam.13078

15. Pizzolitto EL, Pizzolitto AC, Pozetti GL. Chemical and microbiological evaluation of the internal surfaces of aluminum tubes both unlined and lined with epoxy resin by means of the stereoscope and scanning electron microscope. Braz J Microbiol. 2001;32(4):340-4. https://doi.org/10.1590/ S1517-83822001000400017

16. Bjerkan G, Witsø E, Bergh K. Sonication is superior to scraping for retrieval of bacteria in biofilm on titanium and steel surfaces in vitro. Acta Orthop. 2009;80(2):245-50. https://doi.org/10.3109/17453670902947457

17. Saravanakumar R, Devi BMP. Surgical site infection in a tertiary care centre, an overview: a cross sectional study. Int J Surg Open. 2019;21:12-6. https://doi.org/10.1016/j.jijso.2019.09.008

18. Alexiou K, Drikos I, Terzopoulo M, Sikalias N, loannidis A, Economou N. A prospective randomised trial of isolated pathogens of surgical site infections (SSI). Ann Med Surg. 2017;21:25-29. https://doi.org/10.1016/j.amsu.2017.07.045

19. $\mathrm{Li} \mathrm{XL}$, Ji GY. Evaluation of the direct relationship between bacterial load on contaminated stainless steel surgical instruments and the holding time prior to disinfection and also to analyse the efficacy of different disinfecting solutions. Biomed Res[Internet]. 2017 [cited 2019 Oct 12];28(10):46807. Available from: https://www.alliedacademies.org/articles/evaluation-of-the-direct-relationship-between-bacterial-load-on-contaminatedstainless-steel-surgical-instruments-and-the-holding-.pdf

20. Mohite ST, Ashok KY, Mahesh RS, Madhavendra K. Effect of holding time on the bacterial load of surgical instruments. J Evol Med Dent Sci. 2016;5(16):763-5. https://doi.org/10.14260/jemds/2016/177

21. Percin D, Sav H, Hormet-Oz HT, Karauz M. The relationship between holding time and the bacterial load on surgical instruments. Indian J Surg. 2015;77(1):16-8. https://doi.org/10.1007\%2Fs12262-012-0725-z

22. Cloutman-Green E, Canales M, Zhou Q, Ciric L, Hartley JC, McDonnell G. Biochemical and microbial contamination of surgical devices: a quantitative analysis. Am J Infect Control. 2015,43(6):659-61. https://doi.org/10.1016/j.ajic.2015.02.017

23. Evangelista SS, Santos SG, Stoianoff MAR, Oliveira AC. Analysis of microbial load on surgical instruments after clinical use and following manual and automated cleaning. Am J Infect Control. 2015;43(5):522-7. https://doi.org/10.1016/j.ajic.2014.12.018

24. Evangelista SS, Guimaraes NR, Garcia NB, Santos SG, Oliveira AC. Effectiveness of manual versus automated cleaning on Staphylococcus epidermidis biofilm removal from the surface of surgical instruments. Am J Infect Control. 2020;48(3):267-74. https://doi.org/10.1016/j. ajic.2019.08.024 
25. Costa DM, Lopes LKO, Tipple AFV, Johani K, Hu H, Deva AK, et al. Evaluation of stainless steel surgical instruments subjected to multiple use/ processing. Infect Dis Health 2018;23(1):3-9. https://doi.org/10.1016/j.idh.2017.08.004

26. Otter JA, Vickery K, Walker JT, Pulcini ED, Stoodley P, Goldenberg SD, et al. Surface-attached cells, biofilms and biocide susceptibility: implications for hospital cleaning and disinfection. J Hosp Infect. 2015;89(1):16-27. https://doi.org/10.1016/j.jhin.2014.09.008

27. Kimkes TEP, Heinemann M. How bacteria recognise and respond to surface contact. FEMS Microbiol Rev. 2020;44(1):106-22. https://doi. org/10.1093/femsre/fuz029

28. Smith K, Araoye I, Gilbert S, Waites K, Camins B, Conklin M, et al. Is retained bone debris in cannulated orthopedic instruments sterile after autoclaving? Am J Infect Control. 2018;46(9):1009-13. https://doi.org/10.1016/j.ajic.2018.02.024

29. Costa DMD, Lopes LKO, Hu H, Tipple AFV, Vickery K. Alcohol fixation of bacteria to surgical instruments increases cleaning difficulty and may contribute to sterilization inefficacy. Am J Infect Control. 2017;45(8):e81-e6. https://doi.org/10.1016/j.ajic.2017.04.286

30. Prior F, Fernie K, Renfrew A, Heneaghan G. Alcoholic fixation of blood to surgical instruments: a possible factor in the surgical transmission of CJD? J Hosp Infec. 2004;58(1):78-80. https://doi.org/10.1016/j.jhin.2004.04.020

31. Lipscomb IP, Pinchin $\mathrm{H}$, Collin R, Keevil CW. Effect of drying time, ambient temperature and pre-soaks on prion-infected tissue contamination levels on surgical stainless steel: concerns over prolonged transportation of instruments from theatre to central sterile service departments. J Hosp Infect. 2007;65(1):72-7. https://doi.org/10.1016/j.jhin.2006.09.025

32. Secker TJ, Hervé R, Keevil CW. Adsorption of prion and tissue proteins to surgical stainless steel surfaces and the efficacy of decontamination following dry and wet storage conditions. J Hosp Infec. 2011;78(4):251-5. https://doi.org/10.1016/j.jhin.2011.03.021 